More Words on Words

Professor Kathleen Daly

School of Criminology and Criminal Justice

Griffith University,

Brisbane, Queensland

AUSTRALIA 4111

of $\quad+61073735-5625$

fax $\quad 073735-5608$

email: k.daly@griffith.edu.au

Paper prepared for Restorative Justice: An International Journal, Vol 1(1) (2013)

Revised 19 January 2013 


\section{More words on words}

\section{Kathleen Daly*}

Words have multiple definitions and meanings. Further complexities arise when words and ideas are translated from one language and culture to another. Christie wrote 'Words on words' in English, but his homeland is Norway. This matters for the words he chooses and for his thoughts on restorative justice, as they are rendered in English. As one of the founders of abolitionism in European criminology, it is not surprising that the term 'conflicts' continues to be central to his analysis. Not crimes, not wrongs, not harms, but conflicts. When Christie (1977) put forward the idea that conflicts have value, it was a wonderful insight, and it is still. To imagine that the content of conflicts could be a type of property, worth mobilising for the betterment of society - that was original. Idealistic too, but it invited reflection on the ability of all society's members (not just 'the professionals') to engage in a wide-ranging discussion about what is right and wrong, or what should be done when conflict emerges. ${ }^{1}$ In his recent essay, Christie (2013) suggests that conflicts can be a basis for improving society and individuals, if they are 'tamed and used in a good way'. He says we need a better term to characterise alternative ways of 'handling conflicts', and restorative justice is not the right term. No, 'it sounds a bad choice'. He proposes 'less heroic' terminology: 'handling conflicts in civil ways'. This is an ambiguous conclusion: is he suggesting we dispense with penal law and use civil law instead? Or is he suggesting that we act with greater civility when handling conflicts? Or is it a combination, a variant of the 'civilisation' thesis (Bottoms, 2003)?

My response to Christie's words is 'more words', with these points. First, 'conflicts', as a term, does not sufficiently encompass all that occurs in human society when individuals, groups, and organisational entities seek to hurt, degrade, and destroy others. We should retain the idea of wrongs, and with it, penal law as one mechanism of response, although not the sole mechanism. Second, I agree with Christie that the term restorative justice should be replaced, but not for the reasons he gives. I propose the term 'innovative justice', which includes a variety of justice mechanisms-administrative, civil, penal, and those in civil

\footnotetext{
* Professor, School of Criminology and Criminal Justice, Griffith University, Brisbane.

${ }^{1}$ Christie's (1977) ideal neighbourhood court is less remarked upon, but it was (and is) a creative way to address wrongs. I consider it in the punishment section.
} 
society-to address wrongs. Third, I agree that reconciliation between parties 'in conflict' or having been wronged should not be expected; this and related ideas such as forgiveness and apology, are hoped for outcomes of justice processes by some advocates, but they are better seen as gifts, unexpected and without anticipation of reciprocity. Fourth, 'offender' and 'victim' are problematic terms, but I do not know how they can be easily replaced. The problem, in part, is the limits of (the English) language; and in part, finding one word to convey a temporally specific status of a person or organisational entity. Fifth, punishment has many meanings, and it is a distasteful term to many; but it is an evolving concept and cannot be willed away.

\section{Conflicts and wrongs}

Conflicts encompass a range of structural social problems, which affect individuals and groups. Thus, war is a conflict; and during war, groups and individuals hurt and kill others. Societal social and economic inequalities create conflicts among individuals and between individuals and the state. The word is serviceable, but only to a point. We also need to ask: what are the acts of 'chaos, destruction, and misery'? Who is culpable, and who is responsible? Perhaps Christie would say that responsibility rests with society, the broad set of social arrangements that spawns conflict. Then, we are left with the acts themselves; and here Christie suggests that we should not presume an offender (or victim) at the outset, but rather, we should be open-minded by asking 'what happened', and we should seek to 'create understanding ... from whole stories'.

I am analysing materials on youths who have been charged with sex offences against their siblings, and I am reading the research and clinical literatures on cases like these. I find that the youths, even those who admit to offending, do not or cannot fully disclose 'what happened' to their parent(s) or legal authorities, although they may to counsellors after many months. 'What happened' in these cases is not a once-off incident, but a pattern of on-going sexual abuse, lasting on average over 40 weeks. ${ }^{2}$ There are many barriers to disclosing the abuse when it is occurring, which unless it is discovered by a parent or other adult, falls on a young victim. ${ }^{3}$ In Australia in recent years, there has been a 'shift in thinking ... from a punitive response to a much more therapeutic response' (Stathopoulos, 2012: 1), that is, from

\footnotetext{
${ }^{2}$ My analysis is based on all youth sex offence cases, including sibling sexual abuse, reported to the police in South Australia over a 6.5-year period; this average (mean) is of the 64 per cent of cases in which the abuse was on-going. Clinical samples of adult survivors typically show a longer duration (see Daly and Wade, 2012).

${ }^{3}$ The average age of the abused sibling was 8; and the abusive sibling, 14.
} 
removing the abusive sibling from the family toward 'holistic responses' that deal with the 'specific needs' of abused and abusive siblings and family members (p. 16). What do we call this behaviour? 'Conflicts' is not apt: the child is not 'in conflict' with her older brother. ${ }^{4}$ If we are to recognise and validate an abused sibling's experiences, we need another word: my preferred term is 'wrongs', or perhaps 'harms'.

Other related examples are the physical and sexual victimisation of children or youth by adults, while in state or religious care; and clergy abuse of children or youth inside and outside institutional walls. The problem with the term 'conflict' is that it evokes (in my mind) a sense of mutual culpability or of diffused responsibility. This is relevant in some circumstances, but not in others. Penal law deals with wrongs, but many wrongs are not necessarily handled by penal law. Other mechanisms such as civil suits, administrative tribunals, redress packages, truth commissions, state compensation or financial assistance, exgratia payments — all of these and other types of mechanisms are and have been used to address wrongs.

\section{Conventional and innovative justice}

Christie equates ‘justice’ with law, and specifically, penal law. He has a particular meaning of justice in mind, as an equality of response to 'like crimes'. I agree with his view that a just response_-defined solely as responding with ‘equal severity' to crime of 'equal seriousness'—does not have real people and real cases in mind. However, there are other types of justice responses (civil and administrative), not just penal responses; in addition, 'alternative’ mechanisms could work alongside criminal, civil, and administrative law; and there are mechanisms in civil society, 'outside' law.

In recognition of this diversity, I propose we view justice mechanisms as residing on a continuum from conventional to innovative. Conventional and innovative are overlapping categories; they are not mutually exclusive and can be combined in hybrid forms. ${ }^{6}$

\footnotetext{
${ }^{4}$ From Daly and Wade (2012: Appendix II); in the set of charged cases, most abused siblings (73 per cent) were female; and nearly all abusive siblings (98 per cent) were male.

${ }^{5}$ Duff (2003) distinguishes between wrongs (criminal law) and harms (civil law); but responses to wrongs can take varied forms and should not be limited to criminal law responses.

${ }^{6}$ These arguments are developed in Daly (2011, 2014), where I review and consider innovative justice mechanisms from a victim's perspective, largely with a common law referent. With respect to 'large-scale state-based conflict', Aertsen (2008: 413, 434) suggests that differing types of justice mechanisms- 'informal, formal, and in-between'-need to be ‘combined in a flexible way'. Our understandings of justice in domestic and transitional justice contexts are beginning to see the strengths of hybrid mechanisms.
} 
Conventional responses are concerned with improvements to evidence gathering, prosecution and trial, and supports for victims in legal contexts. They may be part of a criminal (or civil) justice system or work alongside of it. Most assume reliance on formal legality and on prosecution, trial, and sentencing/judgment. Other conventional responses include victim impact statements, specialist courts, civil litigation, state-based compensation or financial assistance, victim advocates, and victim lawyers. Innovative responses may work alongside of or be integrated with criminal justice, be part of administrative procedures, or operate in civil society. They include mediated meetings or conferences of victims and offenders; informal justice mechanisms; truth-telling or truth-seeking; reparations packages having material elements (compensation, other forms of assistance) and symbolic elements (apologies, days of remembrance, and memorials); and people’s tribunals, documentary and street theatre, and other types of art and activist projects in civil society. ${ }^{7}$

There are advantages to conceptualising justice this way. First, when viewing conventional and innovative responses not as fixed or oppositional, we can recognise their dynamic quality, capacity for change, and interdependence. Second, innovative responses are a broad set of justice mechanisms of which restorative justice is just one type. I am proposing that 'innovative justice' be used as an umbrella concept, which contains a variety of justice mechanisms ${ }^{8}$ that can provide more openings for participation and voice, and for victim validation and vindication, and offender accountability.

The 'restorative' element in restorative justice has problems, as Christie notes. This occurs when people get stuck in a too literal interpretation of the words restorative or restoration. A major proponent has argued that 'restorative justice [is] about restoring victims, restoring offenders, and restoring communities’ (Braithwaite, 1999: 1), but I believe restorative justice is better viewed as a nominal concept that stands for a set of activities (typically associated with face-to-face meetings with admitted offenders, victims, and relevant others; but including other practices), rather than as literally and narrowly being about 'restoring'. This conceptual shift is important in debating the appropriateness of restorative justice in cases of gendered violence (Curtis-Fawley and Daly, 2005). As Christie observes, 'She moved out ... It is all over'. There is nothing in the relationship to restore. The problem with restoration, and its companion term, reparation, is far deeper and more

\footnotetext{
${ }^{7}$ Some of these mechanisms feature more in transitional justice contexts than in domestic contexts, but adaptation across contexts is possible.

${ }^{8}$ I am interested to identify and understand justice mechanisms, not to imagine a justice system or type of justice (e.g., transformative justice).
} 
significant than this. These terms are defined differently, depending on a writer's disciplinary frame of reference, and whether the focus is on domestic or international or transitional justice (Daly and Proietti-Scifoni, 2011). Although we are familiar with the problems of defining restorative justice, the situation is worse for reparation and restoration, especially when these terms are applied to domestic justice contexts.

\section{Recognition and understanding}

If we imagine two protagonists (along with their friends, kin, or others), who are brought 'so close that they can see each other', as Christie says, we may hope to see a mutual recognition and understanding of the other. This is the limit of what we should hope for. Even then and depending on the context in which meetings occur, we should not expect to see recognition and understanding most of the time. ${ }^{9}$ To expect more than this-reconciliation, forgiveness, a sincere apology — is to expect too much. Wonderful, if it happens, but do not expect it. On all these matters, I concur with Christie. Realities - the real stories of restorative justice-are some distance from advocates’ rosy pictures (Daly, 2006).

\section{Offenders and victims}

We know that many offenders have been victimised, and that victims have offended; further, for some offences, it may be difficult to discern who is the 'offender', and who, the 'victim'. There should be no fixed status of 'offender' and 'victim' over time, although it does seem to stick. ${ }^{10}$ Worse, some offenders become identified for life by their wrongs to others, as in 'murderer', 'sex offender', and 'thief' — other examples of being 'imprisoned in the term', as Christie says. This can be overcome if we prefaced all of our commentary with the disclaimer that the nouns of 'offender' and 'victim' stand for a much longer string of words, e.g., a 'person, group, or organisational entity, who has alleged to have harmed or wronged another' or 'a person (etc.) who has admitted to harming or wronging another'; and 'a person who has alleged to have been harmed or wronged', etc. We cannot keep repeating this string

\footnotetext{
${ }^{9}$ This depends on the socio-legal context, i.e., how victims are recruited or volunteer to participate in justice activities. When there is a high degree of victim choice (as in adult pre-sentence conference schemes or prison meetings), the situation is completely different compared to when victims have little or no choice because recruitment is offender-centred (as in most youth diversionary conference schemes).

${ }^{10}$ In the gendered violence and the transitional justice literatures, the term 'survivor' is used instead (or alongside) of victim to designate a change in a person's victimisation status over time, and as a term of empowerment.
} 
over and over again; we need one word to represent the many words. That is the reason we require 'simplified terms'. 11

Christie makes several points about the words offender and victim. For offender, he suggests that we need to be open-minded at the start of a 'conflict': we cannot assume a victim was blameless, nor that an offender is fully culpable. He is also concerned that 'a strong stigmata overshadows other sides of the person'. For his first concern, we rely on the police to determine 'what happened;' and I suspect that few members of complex societies have the time or inclination to investigate further. ${ }^{12}$ Christie does not give us the name for the person or organisational entity who, upon an investigation of 'what happened', admitted to hurting another, without defence or excuse. At that point, we may agree that the person is an offender, the term to describe someone who has offended against another. ${ }^{13}$ For the second, Christie is concerned with the labelling effects of the term 'offender'. That is addressed by Braithwaite's (1989) concept of reintegrative shaming: censure the act as bad, but see the person as good and capable of change.

For victim, Christie is concerned that aspects of the 'whole story' are lost through the 'black and white' penal lens. This occurs within a criminal trial; but more information and complexities do emerge, and more of the 'whole story' can come forward in face-to-face meetings such as youth justice conferences, when admitted offenders meet victims. Again, I do not wish to paint a rosy picture because important details in the 'whole story' may not be revealed by those involved, particularly when victims are young. Further, for some offences (especially youth peer assaults), both protagonists may see themselves as 'the victim' (Daly, 2008). In these cases, the term 'victim' does not pose an impediment to the group's discussion, although the question of who is the victim may be challenged. I suspect Christie may see this as optimal, although my research finds that it can also promote re-victimisation when a person's experience of harm is minimised or denied. Other examples come to mind in our research on sibling sexual abuse. In the conferences for these cases, a parent (typically a mother) has a dual role in representing her abused child and supporting her abusive

\footnotetext{
${ }^{11}$ I am open-minded about identifying new terms, but Christie’s person who 'complains' and the other, who 'returns the complains', would not be my first choice! Offending and victimisation are socially constructed; they reflect actions, reactions, and social processes of categorisation. A gerund (verbal noun) may be better able to create this sense of dynamism than a noun.

12 There are exceptions, among them: journalists are important investigators, and many people handle wrongs themselves or report them to others (e.g., religious actors, counsellors or support workers), without calling the police.

${ }^{13}$ Of course, this person may also have been wronged, as part of on-going dispute or during the instant offence, but I cannot consider these additional complexities here.
} 
child/youth. It is a difficult role, but it makes sense to a parent who loves both children and wants to 'be there' for both of them. For a parent, the terms victim and offender are not the problem. Rather, it is being made to ‘tell the story' over and over again to those who inquire (often, but not always, the professionals). A desire to understand and hear the 'whole story' sounds appealing, but we need to be aware of how it affects those who must tell the story (again).

\section{Punishment}

Restorative justice classics by Eglash, Barnett, and Zehr were ‘against' punishment (see Daly, 2013). Christie (1977, reprinted 2003) was unusual among the classics in that he had a place for punishment in his ideal neighbourhood court. Paraphrasing and quoting from the reprinted text (2003: 63-64), Christie said the court is 'victim-centred' and 'lay oriented', and has four stages. The first is to establish that a law has been broken and the right person is identified. The second is to focus on 'the victim's situation' and what can be done to address it by the offender, then the local neighbourhood, and then the state. After all of this occurs, the third stage is 'an eventual decision on punishment', which is 'the suffering which the judge found necessary to apply in addition to those unintended constructive sufferings the offender would go through in his restitutive actions [for] the victim’ (emphasis in original). The last stage, which is post-sentence, is 'service to the offender' to address social, educational, medical ... [needs]'.

Although these ideas were presented many years ago, it is of interest to see how Christie imagined the contingency of punishment in his ideal court. 'Maybe nothing could be done or nothing would be done. But neighbourhoods might find it intolerable that nothing happened'.

There are several positions in the punishment debate in restorative justice. ${ }^{14}$ Duff (2003) assumes the necessity of punishment to achieve restoration; by punishment, he means wrongdoers must suffer remorse and censure, and that reparation must be burdensome. At the other end of continuum, Walgrave (2008) views punishment as incompatible with restorative justice; he imagines that in most cases, restoration can be achieved more effectively without a decision-maker intending to cause suffering. Taking a mid-way position is London (2011), who like Duff, sees punishment as compatible with restorative justice, although he does not view punishment as necessary to achieve restoration; rather, it is

\footnotetext{
${ }^{14}$ My summary here simplifies more complex arguments. I would add that the authors have in mind only domestic contexts of responding to wrongs; in the transitional justice literature, authors are able to bifurcate punishment of offenders from reparation to and support of victims.
} 
introduced after other means of restoring trust are found to be inadequate. Christie's earlier article (1977) and more recent (2013) thinking ('the outcome of a meeting between conflicting parties might end in satisfaction for both of them') come closest to London's idea of punishment as a contingent decision.

It is not practical or desirable to be 'against' punishment, however authors may define this term. This is because punishment is an evolving concept and social practice; and although we may desire to see it become 'more civilised' or humanised, that is not the same as being 'against' it. The moral intuition that an offender should 'repay' wrongs remains strong, in the same way that Christie (1977) imagined that 'neighbourhoods might find it intolerable that nothing happened'. Punishment, as a word and idea, cannot be willed away.

Words, more words. Thank you, Nils.

\section{References}

Aertsen, I (2008) 'Racak, Mahane Yehuda and Nyabyondo: Restorative Justice between the Formal and Informal' in I Aertsen, J Arsovska, H Rohne, M Valinas, and K Vanspauwen (eds) Restoring Justice after Large-Scale Conflicts: Kosovo, DR Congo and the Israeli-Palestinian Case (Willan Publishing, Collumpton).

Bottoms, AE (2003) 'Some Sociological Reflections on Restorative Justice' in A von Hirsch, J Roberts, AE Bottoms, K Roach, and M Schiff (eds) Restorative Justice and Criminal Justice: Competing or Reconcilable Paradigms? (Hart Publishing, Oxford).

Braithwaite, J (1989) Crime, Shame and Reintegration (Cambridge University Press, Cambridge).

Christie, N (1977) ‘Conflicts as Property’ 17 British Journal of Criminology 1-15. Reprinted in G Johnstone (ed) (2003) A Restorative Justice Reader (Willan Publishing, Collumpton).

Curtis-Fawley, S and Daly, K (2005) 'Victim Advocacy Groups and the Idea of Restorative Justice’ 11 Violence Against Women 603-38.

Daly, K (2006) 'The Limits of Restorative Justice’ in D Sullivan and L Tifft (eds) Handbook of Restorative Justice (Routledge, New York). (2008) 'Girls, Peer Violence, and Restorative Justice' 41 Australian and New Zealand Journal of Criminology 109-37. 
(2011) 'Conventional and Innovative Justice Responses to Sexual Violence’ ACSSA Issues 12 (Australian Centre for the Study of Sexual Assault, Australian Institute of Family Studies, Melbourne).

(2013) 'The Punishment Debate in Restorative Justice’ in J Simon and R Sparks (eds)

The SAGE Handbook of Punishment and Society (SAGE Publications Ltd, London). (2014) 'Reconceptualising Sexual Victimisation and Justice' forthcoming in I

Vanfraechem, A Pemberton, and F Ndahinda (eds) Routledge International Handbook of Victimology (Routledge, London). Pre-print available at www.griffith.edu.au/professional-page/professor-kathleen-daly/publications (Part 3).

Daly, K and Wade, D (2012) South Australia Juvenile Justice and Criminal Justice (SAJJCJ) Technical Report No. 5: In-Depth Study of Sexual Assault and Family Violence Cases, Part II, Sibling Sexual Assault, Other Sexual Assault, and Youth-Parent Assault (School of Criminology and Criminal Justice, Griffith University, Brisbane).

Daly, K and Proietti-Scifoni, G (2011) ‘Reparation and Restoration’ in M Tonry (ed) The Oxford Handbook of Crime and Criminal Justice (Oxford University Press, New York). Duff, RA (2003) 'Restoration and Retribution' in in A von Hirsch, J Roberts, AE Bottoms, K Roach, and M Schiff (eds) Restorative Justice and Criminal Justice: Competing or Reconcilable Paradigms? (Hart Publishing, Oxford).

London, R (2011) Crime, Punishment, and Restorative Justice: From the Margins to the Mainstream (Lynne Rienner Publishers, Boulder, CO)

Stathopoulos, M (2012) ‘Sibling Sexual Abuse’ ACSSA Research Summary (Australian Centre for the Study of Sexual Assault, Australian Institute of Family Studies, Melbourne).

Walgrave, L (2008) Restorative Justice, Self Interest and Responsible Citizenship (Willan Publishing, Collumpton). 